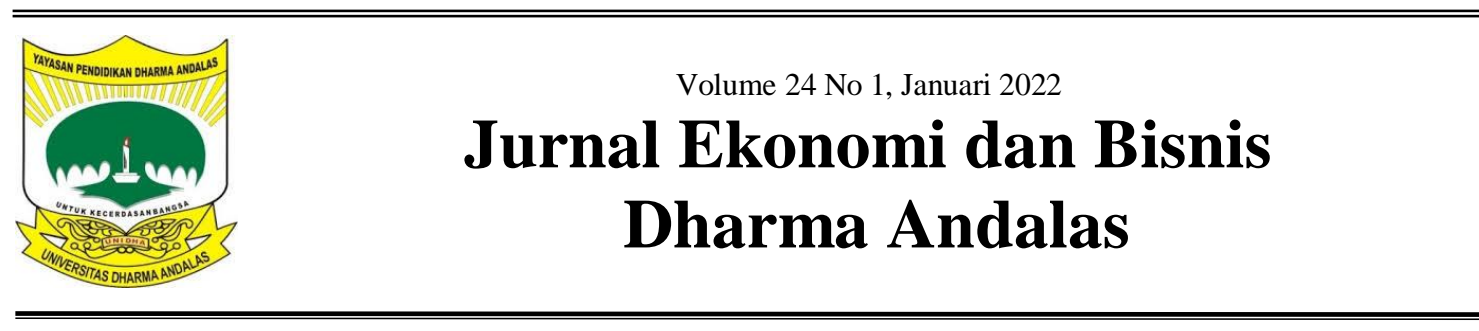

\title{
Persepsi Baby Boomer Terhadap Persiapan Keuangan Memasuki Masa Pensiun Pada Karyawan Perbankan di Kota Padang
}

\author{
Riani Sukma Wijaya ${ }^{1}$, Nini ${ }^{2}$. \\ Fakultas Ekonomi Ekonomi dan Bisnis, Universitas Dharma Andalas Padang ${ }^{1,2}$ \\ email: rianisukmawijaya@unidha.ac.id ${ }^{l}$ \\ niniazwar@gmail.com ${ }^{2}$
}

\begin{abstract}
The aim of this study is to examine the perception of Baby Boomers in preparing their finances, financial planning and financial management for entering retirement. How they manage their finances with the management of family resources so. The analytical method used is qualitative analysis with the data analysis technique used is the waterfall model. Participants of the research was Convesioanal Bank employees in Padang City who are about to retire._Descriptive information about the sample was collected using a form containing personal data from the respondents and a list of questions to answer the research problem. Qualitatively, descriptive method is used to analyze data from respondents. The results of this study, respondents are more likely to invest their finances by buying stocks on the grounds that their finances are more secure and promise good returns. From a financial planning perspective, Baby Boomers plan their finances by saving some of their retirement money and the other half they will use for business activities by using consultant services to make their financial plans, and For financial management, some respondents are confused in managing their finances, because they do not know for sure What will their life be like in the future.
\end{abstract}

Keywordsc, financial planning, and financial management, retiremen, bank

\begin{abstract}
ABSTRAK
Tujuan dari penelitian ini untuk menguji presepsi Baby Boomer dalam mempersiapkan keuanganya, perancangan keuangan dan pengelolaan keuangan untuk memasuki masa pensiunan Bagaimana mereka mengatur keuangan mereka dengan adanya manajemen sumberdaya keluarga yang mana nantinya mereka dapat mengelola keuangannya dengan benar. Metode analisi yang digunakan yaitu analisis kulaitatif dengan teknik analisa data yang digunakan yaitu waterfall model. Partisipan dari penelitian karyawan Bank Convesioanal yang ada di Kota Padang yang akan memasuki masa pensiunan. Informasi secara deskriptif tentang sampel dikumpulkan dengan formulir yang berisi data pribadi dari responden dan daftar pertanyaan untuk menjawab permasalahan penelitian. Secara kualitatif, metode deskriptif di gunakam untuk menganalisa data dari responden. Hasil dari penelitian ini, responden lebih cendrung untuk menginvestasikan keuangan mereka dengan membeli saham dengan alasan keuangan mereka lebih aman dan menjanjikan retur yang baik, Dari sisi perencanaa keuangan Baby Boomer merencanakan keuangan mereka dengan menabung sebagian uang pensiunan dan setengahnya lagi akan mereka gunakan untuk kegitan usaha dengan mengunakan jasa konsultan untuk membuat perencanaan keuangan mereka, dan Untuk pengelolaan keuangan, sebagaian
\end{abstract}


responden bingung dalam penglolaan keuangannya, karena mereka tidak mengetahui pasti kehidupan mereka seperti apa kedepannya.

Keywords:, perencanaan keuangan,pengelolaan keuangan, pensiun, bank

\section{PENDAHULUAN}

Perencanaan

keuangan

merupakan sesuatu hal yang harus di pertimbangkan untuk Baby Boomer sebelum memasuki mas pensiunannya, hal ini akan berdampak kepada kehidupan mereka setelah pensiunan nanti, Berdasarkan data dari menteri keuangan di tahun 2014 yang mengatakan bahwa terdapat sekitar 5\% dari total jumlah tenaga kerja yang tercatat memiliki program perencanaan pensiunan. Masyarkat Indonesia masih terutama bagi yang akan memasuki masa pensiunannya maih terlalu rendah dalam hal perencanaan keuangannya stelah memasuki mas pensiunan nanti

Asnita mengungkapkan 'Bahwa setidaknya terdapat 7 fakta yang ada saat ini mengenai masa pensiun yaitu sebanyak $38 \%$ pensiunan tidak siap secara finansial untuk menjalani masa pensiun yang nyaman, sebanyak $47 \%$ pensiunan merasa bahwa aspirasinya tidak akan tercapai dan tidak terealisasi, sebanyak $53 \%$ para pensiunan disaran untuk menabung di waktu muda mereka dengan cara menisihkan sebagian pendapatan mereka, ada sebanyak 63\% kekawatiran pensiunan ketika memasuki masa msa pensiunan nanti merka tidak memiliki sejumlah uang atau cukup uang untuk meopang kehidupan merka nantinya, sebanyak $70 \%$ pensiunan memerasa menyesal karena tidak berfikir atau berkeinginan menabung di waktu mudanya sehinga di waktu tua tidak memiliki apapun dan bergantung kepada anak mereka, sekitar 4 dari 5 orang menunda pension, karena tidak punya cukup dana untuk digunakan ketika tidak lagi bekerja dan hanya $5,06 \%$ tenaga kerja di Indonesia yang memiliki dana pension di masa tuanya nanti.. Selain itu saat ini data menunjukkan angka harapan hidup di Indonesia semakin panjang, yaitu 67 tahun untuk pria dan 74 tahun untuk wanita. Kondisi tersebut menjadi salah satu faktor yang memaksa masyarakat untuk kembali bekerja setelah melewati usia produktif karena tidak memiliki dana pensiun yang cukup. Persiapan menghadapi masa pensiun dari segi finansial dan pengelolaanya sudah menjadi sangat penting agar masa pensiun dapat dinikmati secara maksimal tanpa ada rasa takut,khawatir dan lainlain. Pentingnya menumbuhkan kesadaran masyarakat akan pentingnya mempersiapkan diri untuk menghadapi masa pensiun sedini mungkin sehingga bisa merancang kondisi keuangan yang baik setelah memasuki masa pensiunan nanti. Oleh karena itu perlu dipersiapkan kondisi yang Hal ini perlu dilakukan agar masyarakat siap menikmati masa pensiun tanpa harus khawatir dengan kondisi keuangan, untuk dapat mempertahankan gaya hidup mereka dimasa pensiun. Untuk itu sudah seharusnya masyarakat Indonesia mempersiapkan masa pensiun sedini mu liti secara kualitatif tentang kesiapan Baby Boomer menghadapi masa pensiunannya dengan Teknik Analisa data menggunakan Snowball dan mengambil 15 orang responden yang terdiri dari 4 orang Wanita dan 11 orang pria di Texas, dari hasil penelitiannya menyatakan bahwa setengah dari responden sudah mempersiapkan masa pensiunannya dan sebagian lagi belum mempersiapkan masa pensiuannya karena mereka mereka akan mendapatkan santunan dari pemerintahnya. Penelitain yagn lain uang di teliti oleh Beverly Bracket yan meneliti tentang perbandingan anatar gnder dalam menglola keuangan sebelum memasuki masa pensiunan dimana permpuan lebih 
baik mengelola keuangan dari pada pria. Beda dengan penelitian sebelumnya dari tahun yang di teliti, negara, responden dan Teknik Analisa data menggunakan Waterfall. Penelitian lain yang dilakukan oleh Sundjaja dkk (2011) mengenai Pola Gaya Hidup dalam Keuangan Keluarga pada unit kerja sebuah institusi pendidikan swasta di Bandung, ditemukan bahwa responden sudah memiliki kebiasaan menabung /berinvestasi dan memiliki asuransi. Dalam penelitian tersebut ditemukan juga bahwa masih kurangnya kesadaran untuk membuat pembukuan sederhana atas pengeluaran dan penerimaan mereka. Berdasarkan paparan diatas, penulis tertarik untuk menggali lebih dalam dengan melakukan penelitian berjudul. "Presepsi Baby Boomer terhadap persiapan keuangan memasuki masa pensiun pada karyawan perbankan di kota Padang"

\section{METODE PENELITIAN}

\section{Pendekatan dan Jenis Penelitian}

Metode penelitian yang

digunakan pada studi ini adalah metode kualitatif. Metode kualitatif sebagai prosedur penelitian yang menghasilkan data deskriptif berupa kata-kata tertulis atau lisan dari orang-orang atau perilaku yang dapat diamati (Lexy J, 2017) Penelitian deskriptif adalah suatu metode penelitian yang menggambarkan semua data atau keadaan subjek atau objek penelitian kemudian dianalisis dan dibandingkan berdasarkan kenyataan yang sedang berlangsung pada saat ini dan selanjutnya mencoba untuk memberikan pemecahan masalahnya dan dapat memberikan informasi yang mutakhir sehingga bermanfaat bagi perkembangan ilmu pengetahuan serta lebih banyak dapat diterapkan pada berbagai masalah. penelitian deskripsi secara garis besar merupakan kegiatan penelitian yang hendak membuat gambaran atau mencoba mencandra suatu peristiwa atau gejala secara sistematis, faktual dengan penyusunan yang akurat (Supardi 2005).

Metode kualitatif ini digunakan karena beberapa pertimbangan yaitu metode kualitatif lebih bisa dan mudah menyesuaikan apabila berhadapan dengan kenyataan ganda, metode ini menyajikan hakekat hubungan antara peneliti dan responden secara langsung dan metode ini lebih peka sehingga dapat menyesuaikan diri dan banyak penajaman pengaruh bersama terhadap pola-pola nilai yang dihadapi peneliti (Ahmad Tanzeh dan Suyitno 2006). Penelitian diarahkan untuk melihat presepsi baby boomer dalam mempersiapkan keuangannya dalam menghadapi masa pensiunan, bagaimana pengololaan keuangannya dan bagimana baby boomer dan bagaimana Baby Boomer merancang keuangannya sebelum memasuki masa pensiunan.

Penerapan pendekatan kualitatif dengan pertimbangan kemungkinan data yang diperoleh di lapangan berupa data dalam bentuk fakta yang perlu adanya analisis secara mendalam. Maka pendekatan kualitatif akan lebih mendorong pada pencapaian data yang bersifat lebih mendalam terutama dengan keterlibatan peneliti sendiri di lapangan. Dalam penelitian kualitatif, peneliti menjadi instrument utama dalam mengumpulkan data yang dapat berhubungan langsung dengan instrument atau objek penelitian (Sugiyono, 2017).

Lokasi dalam penelitian ini adalah Kota Padang yang di tujukan kepada karyawan Bank Convensional yang akan memasuki masa pensiunan.

\section{Kehadiran Peneliti}

Sesuai dengan jenis penelitian yang peneliti lakukan, untuk memperoleh data sebanyak mungkin dan mendalam selama kegiatan penelitian di lapangan 
dalam penelitian kualitatif, peneliti sendiri atau dengan bantuan orang lain merupakan alat pengumpul data utama sehingga kehadiran peneliti di lapangan mutlak diperlukan (Lexy J. Moleong, 2017). Dengan kata lain kehadiran peneliti sangat diperlukan untuk mengkaji lebih mendalam tentang rumusan masalah yang dibahas.

Peneliti akan melakukan observasi langsung, melakukan wawancara dengan para pensiunan karyawan yang bekerja di Bank yang ada di kota Padang kurang lebih 20 orang yang akan memasuki masa pensiunan. Untuk mendukung pengumpulan data dari sumber yang ada di lapangan, peneliti memanfaatkan buku tulis dan bolpoin sebagai pencatat data.

Peneliti sebagai instrumen kunci berusaha memperoleh data tentang kesiapan, pelaksanaan, kendala, hambatan dan strategi menghadapi kendala atau hambatan tersebut sesuai dengan kenyataan yang ada di lapangan, agar informasi yang dikumpulkan benarbenar relevan dan terjamin keabsahannya.

Sumber data menurut Suharsimi Arikunto adalah subjek dari mana data itu diperoleh.Sumber data meliputi dua jenis : pertama sumber data primer, yaitu data yang diambil dari sumber pertama yang ada di lapangan (Arikunto, Suharsimi. 2016). Atau data yang diperoleh langsung dari objek penelitian yang berasal dari observasi dan juga wawancara, dalam penelitian ini data primer diperoleh peneliti dari karyawan-karyawan Bank Convensional yang akan memasuki masa pension dengan maengajukan sejumla pertanyaan.. Dan data yang kedua data sekunder, yaitu data yang diperoleh dari buku-buku dan situs- situs internet yang berisi tentang pengelolaan keuangan bagi pensiunan.

Metode pengumpulan data adalah teknik atau cara yang dapat digunakan oleh peneliti untuk mengumpulkan data, serta instrumen pengumpulan data adalah alat bantu yang dipilih dan digunakan oleh peneliti dalam kegiatannya mengumpulkan data agar kegiatan tersebut menjadi sistematis dan lebih mudah.( Ridwan, 2006).

Dalam penelitian ini, peneliti bertindak sebagai instrumen sekaligus sebagai pengumpul data. Prosedur yang di pakai dalam pengumpulan data yaitu: (1) Observasi, (2) Wawancara, dan (3) Dokumentasi, yaitu sebagai berikut:

\section{a) Observasi}

Observasi adalah teknik pengumpulan data yang dilakukan melalui pengamatan, dengan disertai pencatatan-pencatatan terhadap keadaan atau perilaku obyek sasaran (Sudaryono, 2017). Dalam hal ini peneliti melakukan pengamatan langsung kepada Baby Boomer yang akan memasuki masa pensiun. Dari hal ini, peneliti mengkaji tentang persiapan sebelum memasuki masa pensiun, apa motivasi yang dipersiapkan setelah pensiun, apakah ada pendapatan lain sebelum memasuki masa pensiunan, apakah memerlukan konsultan untuk mengatur keuangan setelah pensiun atau tertarik untuk menanamkan investasi.

b) Wawancara

Wawancara merupakan metode pengumpulan data dengan cara bertanya langsung (berkomunikasi langsung) dengan responden. Dalam berwawancara terdapat proses interaksi antara pewawancara dengan respoden (Ibit, 2017).

Wawancara secara garis besar dibagi menjadi dua, yakni wawancara tidak terstruktur dan wawancara terstruktur. Wawancara tak terstruktur sering juga disebut wawancara mendalam, wawancara intensif, wawancara kualitatif, dan wawancara terbuka (open ended interview), wawancara etnografis. Sedangkan 
wawancara terstruktur sering juga disebut wawancara baku (standardized interview) yang susunan pertanyaannya sudah ditetapkan sebelumnya (biasanya tertulis) dengan pilihan-pilihan jawaban yang juga sudah disediakan (Sudaryono, 2017)

Wawancara ini ditunjukan untuk menggali pemahaman persiapan sebelum memasuki masa pensiun, apa motivasi yang dipersiapkan setelah pensiun, apakah ada pendapatan lain sebelum memasuki masa pensiunan, apakah memerlukan konsultan untuk mengatur keuangan setelah pensiun atau tertarik untuk menanamkan investasi.

Interview merupakan alat pengumpul informasi dengan cara mengajukan sejumlah pertanyaan secara lisan untuk dijawab untuk secara lisan untuk dijawab secara lisan pula.dalam tahapan wawancara ini peneliti akan mengajukan 10 pertanyaan yang dirangkum dalam bentuk kuisioner.

c) Dokumentasi

Teknik dokumentasi dipergunakan untuk melengkapi sekaligus menambah keakuratan, kebenaran data atau informasi yang dikumpulkan dari bahanbahan dokumentasi yang ada di lapangan serta dapat dijadikan bahan dalam pengecekan keabsahan data.

Analisis dokumentasi dilakukan untuk mengumpulkan data yang bersumber dari arsip dan dokumen yang berada ditempat penelitian atau yang berada diluar tempat penelitian yang ada hubungannya dengan penelitian tersebut (Ibit, 2017). Metode ini digunakan untuk mengumpulkan data yang sudah tersedia dalam catatan dokumen. Fungsinya sebagai pendukung dan pelengkap bagi data-data yang diperoleh melui observasi dan wawancara.

\section{Teknik Analisis Data}

Analisis data dalam penelitian berlangsung bersamaan dengan proses pengumpulan data. Diantaranya adalah melalui tiga tahap waterfall model, yaitu reduksi data, penyajian data, dan verifikasi (Darisman A and Widianto $M$. $\mathrm{H}, 2019$ ). Analisis data kualitatif adalah upaya yang dilakukan dengan jalan bekerja dengan data, mengorganisir data, memilah-milahnya menjadikan satuan yang dapat dikelola, mensistensikannya, mencari dan menemukan pola, menentukan apa yang penting dan apa yang dipelajari, dan memutuskan apa yang dapat diceritakan kepada orang lain (Lexy J. Moeleong, 2017)

Analisis berarti mengkaji data yang diperoleh dari lapangan dengan cara mengorganisasikan data ke dalam kategori, menjabarkan kedalam unit-unit, memilih mana yang penting dan akan dipelajari, dan membuat kesimpulan sehingga mudah difahami oleh diri sendiri maupun orang lain (Sudaryono, 2017). Adapun prosedur pengembangannya data kualitatif adalah :

Data collecting, yaitu proses pengumpulan data.

a. Data editing, yaitu proses pembersihan data, artinya memeriksa kembali jawaban apakah cara menjawabnya sudah benar.

b. Data reducting, yaitu data yang disederhanakan, diperkecil, dirapikan, diatur dan dibuang yang salah.

c. Data display, yaitu penyajian data dalam bentuk deskriptif verbalitas.

d. Data verifikasi, yaitu pemeriksaan kembali dari pengulangan data.

e. Data konklusi, yaitu perumusan kesimpulanhasil penelitianyang disajikan, baik perumusan secara umum ataupun khusus (Ahmad Tanzeh, 2004).

\section{Pengecekan Keabsahan Data}

Penelitian ini berangkat dari data.

Data adalah segala-galanya dalam penelitian. Oleh karena itu, data harus benar-benar valid. Ukuran validitas suatu penelitian terdapat pada alat untuk menjaring data, apakah tepat, benar, 
sesuai dan mengukur apa yang seharusnya diukur. Alat untuk menjaring data penelitian kualitatif terletak pada penelitian yang dibantu dengan metode interview, observasi, dan metode dokumentasi. Dengan demikian, yang diuji ketepatannya adalah kapasitas peneliti dalam merancang fokus, menetapkan dan memilih informan, melaksanakan metode pengumpulan data, menganalisis dan menginterprestasi dan melaporkan hasil penelitian yang kesemuanya itu perlu menunjuk konsistensinya satu sama yang lain. (Komariyah Riduwan, (ed), )

Ada beberapa cara meningkatkan kredibilitas data (kepercayaan) terhadap data kualitatif antara lain perpanjangan pengamatan, trianggulasi, dan diskusi dengan teman sejawat. Penjelasan dari ketiganya, adalah sebagai berikut :

\section{a. Perpanjangan pengamatan}

Sulit mempercayai hasil penelitian kualitatif apabila peneliti hanya sekali saja ke lapangan. Walapun dengan dalih data bahwa dalam waktu seharian itu dipadatkan dan kumpulkan data sebanyaknya. Peneliti musti memperpanjang pengamatan karena hanya datang sekali sulit memperoleh link dan chemistry/enggagemant dengan informan. Perpanjangan pengamatan memungkinkan terjadinya hubungan antara peneliti dengan narasumber menjadi akrab, semakin terbuka, saling mempercayai sehingga tidak ada informasi yang disembunyikan lagi dan peneliti dapat memperoleh data secara lengkap (Sudaryono, 2017)

Dalam pengumpulan data kualitatif, perpanjangan waktu dalam penelitian ini dilakukan dengan pertimbangan situasi dan kondisi di lapangan serta data yang telah terkumpul. Dengan perpanjangan waktu tersebut peneliti dapat meningkatkan derajat kepercayaan atas data yang dikumpulkan, mempertajam rumusan masalah dan memperoleh data yang lengkap.

\section{b. Trianggulasi}

Karena yang dicari adalah katakata, maka tidak mustahil ada kata- kata yang keliru yang tidak sesuai antara yang dibicarakan dengan kenyataan sesungguhnya. Hal ini bisa dipengaruhi oleh kredibilitas informannya, waktu pengungkapan, kondisi yang dialami dan sebagainya (Sudaryono, 2017).

Dalam penelitian ini, mengunakan Tianggulasi Metode, dimana peneliti membandingkan data hasil wawancara mendalam dengan data hasil observasi partisipan, serta dari dokumen yang berkaitan. Selain itu, peneliti menerapkan trianggulasi metode dengan mengadakan pengecekan derajat kepercayaan beberapa subjek penelitian selaku sumber data dengan metode yang sama.

Validitas eksternal dalam penelitian kualitatif merupakan persoalan empiris bergantung dengan kesamaan konteks, agar dapat dipahami orang lain. Dalam penelitian ini peneliti menyediakan laporan deskriptif yang rinci, jelas, sistematis dan empiris sehingga pembaca memperoleh informasi yang jelas tentang temuan penelitian ini.

c. Diskusi dengan teman sejawat

Walaupun penelitian ini dilakukan sendiri, tetapi penelitian ini mencakup kategori dari masing-masing peneliti. Peneliti mendiskusikan hasil temuan dengan teman sejawat. Peneliti berdiskusi dengan teman sejawat yang memiliki pengetahuan tentang presepsi Baby Bomer terhadap persiapan keuangan setelah pension.

\section{Tahap-Tahap Penelitian}

Dalam melakukan penelitian ini peneliti memakai empat tahapan, yaitu :

a) Tahapan Persiapan

Dalam tahapan persiapan ini peneliti mulai mengumpulkan bukubuku atau teori-teori yang berkaitan 
dengan pembahasan penelitian mengenai presepsi Baby Bomer terhadap persiapan keuangan yang akan memasuki masa pensiun

b) Tahap Pelaksanaan

Tahap ini dilaksanakan dengan cara mengumpulkan data-data yang berkaitan dengan fokus penelitian dari lokasi penelitian. Dalam proses pengumpulan data ini peneliti menggunakan metode observasi. Setelah mendapat ijin dari pihak Bank convensional untuk meminta data karyawan yang akan memasuki masa pensiuin, peneliti kemudian mempersiapkan diri untuk menghubingi karyawan tersebut untuk membuat janji terlebih dahulu, kemudian menjalin keakraban dengan responden dalam berbagai aktifitas, agar peneliti diterima dengan baik dan lebih leluasa dalam memperoleh data yang diharapkan. Kemudian peneliti melakukan pengamatan lebih mendalam, wawancara dan mengumpulkan data-data dari dokumentasi.

c) Tahap Analisis Data

Pada tahapan ini peneliti menyusun semua data yang telah terkumpul secara sistematis dan terinci sehingga data tersebut mudah dipahami dan temuannya dapat diinformasikan kepada orang lain secara jelas. Setelah peneliti mendapatkan data yang cukup dari lapangan, peneliti melakukan analisis terhadap data yang telah diperoleh dengan teknik analisis yang telah penulis uraikan diatas, kemudian menelaahnya, membagi dan menemukan makna dari apa yang telah diteliti.

d) Tahap Pelaporan

Tahap ini merupakan tahap terakhir dari tahapan penelitian yang peneliti lakukan. Tahap ini dilakukan dengan membuat laporan tertulis dari hasil penelitian yang telah dilaksanakan.

\section{HASIL DAN PEMBAHASAN}

Sesuai dengan perumusan masalah, secara umum tujuan dilaksanakannya penelitian ini dapat dibagi menjadi tiga kelompok utama yaitu bagaimana persiapan Baby Boomer dalam mengelola keuagnannya, bagaiamana merencanakan keuanganya dan bagaimana mengelola keuagannya untuk menghadapi masa pensiunannya. Penelitian ini mewancarai 15 orang karyawan Bank swasta di Kota Padang yang akan memasuki masa pensiunan. Item pertanyaan yang di ajukan ke responden berjumlah 10 item pertanyaan dengan langsung mewawancarai responden. Hasil dari penelitian ini akan di bagi kedalam empat kelompok yaitu a). deskripsi demografi dari partisapan. b). Tema yang muncul dari responden dari pertanyaan yang diberikan. c). menganalisa jawaban yang diberikan responden terhadap pertanyaan yang diberikan.

Deskripsi Responden

Respon terdiri dari 15 orang karyawan Bank Swasta yang berumur antara 35 tahun sampai 50 tahun, disini peneliti menyajikan gender, umur, pendidikan, pendapatan, dan status pernikahan

\section{Tabel 1}

Deskripsi Responden

\begin{tabular}{|c|c|c|}
\hline Keterangan & Jumlah & (\%) \\
\hline \multicolumn{3}{|l|}{ Gender } \\
\hline Male & 4 & 27 \\
\hline Female & 11 & 73 \\
\hline \multicolumn{3}{|l|}{ Umur } \\
\hline $35-44$ & 7 & 47 \\
\hline $45-50$ & 8 & 53 \\
\hline \multicolumn{3}{|l|}{ Pendidikan } \\
\hline SLTA & 2 & 13 \\
\hline S1 & 11 & 74 \\
\hline S2 & 2 & 13 \\
\hline
\end{tabular}




\begin{tabular}{lcc}
\hline \multicolumn{1}{c}{ Keterangan } & Jumlah & (\%) \\
\hline Marital Status & 2 & 13 \\
Lajang & 13 & 87 \\
Menikah & 0 & 0 \\
Cerai & 0 & 0 \\
Janda & & \\
Pendapatan Per Tahun & 2 & 13 \\
Rp 60.000.000 atau Kurang & 11 & 74 \\
Rp 60.000.000 - Rp 120.000.000 & 2 & 13 \\
Rp 120.000.000 lebih & \\
\hline
\end{tabular}

Profil Responden berdasarkan Gender dan Umur

Dilihat dari tabel diatas jumlah responden terbanyak di jawab oleh ibuibu yaitu sekitar 11 orang dan selebihnya diikuti oleh bapak-bapak yaitu sekitar 4 orang dengan umur rata antara 35 tahun sampai 44 berjumlah 7 orang yang disebut dengan young baby boomer dan umur antara 45-50 tahun berjumlah 8 orang yang disebut old baby boomer

\section{Profil Responden Berdasarkan Tingkatan Pendidikan}

Sebagian besar responden yang berpartisipasi didalam peneliitan ini memiliki pendidikan formal setara sarjana (S1) yaitu berjumlah 11 rang responden. Kelompok responden berikutnya adalah mereka yang memiliki tingkat pendidikan S2 yaitu berjumlah 2 orang, sedangkan sisanya adalah responden dengan tingkatan pendidikan SLTA

\section{Profil Responden Berdasarkan Marital Status dan jumlah pendapatan per tahun}

Berdasarkan pengelompokan responden yang berpartisipasi dalam penelitian ini berstatus menikah dengan jumlah responden 13 orang dan 2 orang berstatus lajang. Jumlah responden berpendapatan antara 60 juta sampai dengan 120 juta pertahun sebanyak 11 orang responden, penghasilan 60 juta per tahun atau kurang sebanyak 2 orang responden, sebelihnya berpenghasilan lebih dari 120 juta per tahun ada 2 orang responden .

Dalam upaya menjawab pertanyaan yang diajukan kepada Baby Boomer melalui wawancara langsung terkait dengan persiapan financial Baby Boomer sebelum memasuki masa masa pensiunan

\section{Persiapan Baby Boomer memasuki masa pensiunan}

Ketika saya melakukan interview yang menanyakan bagaimana mereka mempersiapkan keuangannya untuk memasuki masa pensiunannya, 8 orang dari reponden menjawab lebih suka menginvestasikan keuangan mereka dalam bentuk saham. Berikut contoh percakapan yang dengan partisipan:

'Kami lebih memilih melakkan investasi dalam bentuk saham dari pada pembelian aset-aset lain, itu dikarenakan investsi dengan membeli saham-saham harganya masih terjangakau dan bersifat fleksible, Selain sifatnya jangka panjang diibaratkan sebagai pengganti menabung, karena resikonya cukup kecil. Oleh karena itu kami membeli saham yang sudah mempunyai tren yang bagus. Dengan melakukan investasi dalam bentuk saham akan memperoleh manfaat di masa yang akan datang dan keuntungan yang menjanikan. Jika suatu saat kita membutuhkan uang maka dapat memperoleh uang dengan cara menjual sebagian saham'

Disamping itu, partisipan juga mempersiapkan sejumlah uang untuk mereka liburan dan membayar sejumlah anggsuran yang sifatnya rutin.

Apa motivasi dari Baby Boomer dalam merencanakan keuangan sebelum memasuki masa pensiunan. Untuk membangun motivasi yang dimiliki oleh Baby Boomer dalam mempersiapkan masa pensiunannya, peneliti meminta mereka mengidentifiakasi motivasi mereka untuk dalam mempersiapkan 
keuangan sebelum pensiunan. Saya memberikan mereka waktu sejenak untuk berfikir untuk menjawab pertanyaan saya berupa a). takut apa tidak jika dimasa pensiunan tidak memiliki financial dibandingkan dengan waktu masih bekerja, b). keinginan hidup yang nyaman, c) Mempersiapakan masa depan anak-anak.

a. Takut atau tidak jika dimasa pensiunan tidak memiliki financial dibandingkan dengan waktu masih. bekerja. Hampir dari setengah partisipan menjawabab tentang takut atau tidaknya jika sudah pensiunan tidak mempunyai keuangan dibandingkan dengan sewaktu mereka masih bekerja.

Partispan sangat takut jika mereka setelah pensiunan tidak memperisapkan keuangannya dengan baik, mereka memberikan contoh kepada orang tua yang tidak mempunyai uang di akhir kehidupan dan akhirnya anak-anak mereka menitipkan orang tua mereka di panti jompo. Oleh karna itu, kami diakhir masa pensiunan kami tidak ingin membebankan keluarga terdekat untuk membiayai hidup kami. Kami harus menjadi sesuatu yang kami inginkan ketika sudah memasuki masa pensiunan, kami ingin menikmati hari-hari yang bahagia dengan keluarga dan orangorang terdekat kami tampa membebankan mereka terhadap hidup kami.

Kami kira mungkin yang paling memotivasi saya adalah ketika melihat ibu saya yang tidak mepunyai uang yang cukup. Orang tua berpikir dia akan kehabisan uang sebelum dia meninggal. Dan saya pikir itu dapat membangkitkan semangat saya untuk memotivasi diri saya untuk memikirkan akhir dari pensiunan saya ini.

Perubahan dengan gaya hidup dari masih bekerja dan sudah pensiun pasti lah tidak akan sama, di waktu bekerja kita bisa membeli apa saja yang diinginkan dengan asumsi bahwa akan terima gaji di bulan berikutnya.

b. Keinginan hidup yang nyaman

Peneliti menghubungakan pertanyaan ini dengan keinginan mereka untuk kenyamanan selama memasuki tahun-tahun pensiunan. Mereka menghagai dirinya mendukung ide-ide yang mereka miliki, bukan tergantung kepada orang lain.

'Saya akan merubah gaya hidup saya setelah pensiunan nanti dan saya berharap tidak akan menjadi beban bagi siapapun. Saya harus merasa nyaman, karena hidup itu harus dinikmati, saya berkerja puluhan tahun untuk mengumpulkan uang agar ketika saya pensiun saya akan menikmati hasil kerja keras saya selama ini, mungkin saya akan melakukan kegitan sosial untuk mengisi hari tua saya atau saya akan duduk-duduk saja menikmati uang atau pergi jalan-jalan dan bisa menikati kebebasan untuk melakukan apapun dan juga mempunyai pilihan bagaimana saya menghaniskan waktu'

c. Mempersiapakan masa depan anakanak

Ada 4 partisipan yang mempersiapkan kehidupan anak-anak mereka sebagai motivator mereka yang valid.

Ke-4 partisipan tersebut berbicara mengambil tanggung jawab untuk masa depan anak-anak mereka dan memastikan bahwa anak-anak kami akan terjamin hidupnya dan mempunyai pendidikan yang lebih tingi.

\section{Perencanaan Keuangan Baby Boomer memasuki masa pensiunan.}

Dalam hal perencanaan keuangan 15 partisipan mempunyai argumen yang berbeda tentang pengelolaan keuangan mereka, 10 diantara partisipan mempunyia jawban yang hampir sama tentang perencanaan keuangan mereka yaitu dengan menabung sebagian uang pensiunan yang mereka terima dan 
setengahnya lagi akan mereka gunakan untuk kegitan usaha dengan mengunakan jas konsultan untuk membuat perencanaan keuangan mereka.

Responden menjawab, 'Saya merasa yakin bahwa setlah pensiun saya bisa melakukan apa saja yang bermanfaat dalam hidup saya, uang yang diterima sebagai pesangon atau tunjangan yang diberikan perusahaan akan saya kelola dengan baik, karena kalau salah dalam pengolaan akan berdampak kepada kehidupan kami. Oleh karena itu sebagian uang yang diperoleh akan di simpang di Bank dan sisanya akan kami gunakan untuk berusaha mungkin dengan membuka lapangan pekerjaan, atau membuka perkebunan sehingga pendapatan yang diteima tetap bisa mempertahankan kehidupan kami dari pada hanya meminta bantuan kepada anak-anak kami'

Beberapa partisipan juga menjawab tentang bagaimana perncanaan keuangan mereka setelah pensiun nanti."Saya akan berencana akan menyewa konsultan untuk perencanaan keuangan saya, denan adanya konsultan saya yakin perencanaan keuangan saya akan lebih terkelola dengan baik, karena saya susah mengubah pola hidup saya, sehingga ketakutan itu muncul, bagaimana jika dihari tua saya tidak bisa mengelola uang dengan benar akan mengakibatkan saya kehilangan segalanya."

'Pendapatan yang saya terima saat sekarang ini belum tentu bisa saya terima lagi dimasa pensiunan saya, tidak seperti pegawai negeri yang menerima uang pensiunanya setiap bulan, pegawai negeri tidak perlu lagi kuatir dari segi financialnya, lain hal nya dengan saya yang harus tetap berusaha untuk mencukupi kebutuhan hidup. Tapi jika pengelolaan uang pensiun di kelola dengan baik, hasilnya juga akan baik dan merasa berkecukupan tampa membebankan orang lain'

\section{Pengelolaan Keuangan Baby Boomer memasuki masa pensiunan}

Beberapa responden tidak terlalu jelas menjelaskan presepsi mereka bagaimna cara mereka mengelola keuangan sebelum memasuki pensuin. 'Saya tidak yakin mengelola keuangan dengan benar dimana saya akan masih ada anak-anak yang akan saya biaya untuk melanjutkan pendidikan yang lebih tinggi dan masih ad juga yang sedang sekolah menengah keatas, sehingga belum terfikir oleh saya bagaimana pengelolaan keuangan yang baik, atau bagian mana yang akan saia prioritaskan, apakah untuk kehidupan saya, atua untuk masa depan anak-anak saya.'

Sebelas orang responden menjawab bahwa "Saya harus mengelola keuangan dengan benar agar di mas pensiunan saya dapat menikamti hasil selama ini dan apa yang menjadi tujuan saya di akhir kehidupan saya dapat terpenuhi sesuai dengan arapan saya. Salah satu contoh yang ingin saya harapkan di waktu pensiun mendatang, ingin membelikan rumah untuk anak-anak saya, maka dari itu lah saya harus mengelola keuangan dengan cara menyisihkan sebagian pendapatan saya untuk ditabung. Saya mengelola keuangan dengan cara membagi tiga dari semua penghailan yang saya terima tiap bulannya, simpanan pertama akan saya gunakan untuk kebutuhan hidup, tabunan kedua akan digunakan untuk masa depan anak saya, dan tabungan yang ketiga untuk simpanan darurat dan saya sangat konsisten"

Untuk pengelolaan keuangan ini saya juga membaca buku-buku mengenai pengelolaan keuangan, mencari jurnaljurnal yang berhubungan dengan pengelolaan keuangan, mempelajari dari 
media-media sosial. Terkadang saya terpengaruh terhadap investasi saham yang menggiurkan, cukup dengan menyetorkan uang, tungu bulan pertama saya akan diberikan persentase keuntungan yang telah disepakati di awal, dan seterusnya apakah tetap menjanjikan keuntungan yang sama? Karena saya tidak mau mengambil resiko sebaiknya uangnya saya tabungkan.

Jadi sebagian responden menjawab bingung atau ragu-ragu dalam pengelolaan keuangan, mereka tidak mengetahui pasti kehidupan mereka seperti apa, dengan adanya uang pensiunan yang mereka terima bisa menghidupi keluarganya dan tidak mau mengambil resiko dalam melakukan investasi dalam bentuk saham. Dan sebagian lagi mereka lebih mempercayakan pengelolaan keuanga mereka dengan menggunakan jasa konsultan, sehingga jelas pengeluaran uang mereka itu untuk kepeluan apa dan seberapa penting keperluan mereka tersebut sehingga tidak ada uang yang terbuang percuma

\section{SIMPULAN}

Penelitian ini manganalisi
presepsi Baby Boomer terhadap persiapan keuanagan sebelum memasuki masa pensiuan pada karyawn Bank di Kota Padang, yang terdiri dari 15 orang responden yang sudah menikah dengan rata-rata umur 45-50 tahun dengan penghasilan lebih dari Rp60.000.000 per tahun. Dilihat dari persiapan Baby Boomer memasuki masa pensiunan, responden lebih cenderung untuk menginvestasikan keuangan mereka dengan membeli saham dengan alasan keuangan mereka lebih aman dan menjanjikan retur yang baik. Selain itu mereka bisa . mencaikan atau mengambil uang nya keika mereka sangat membutuhkannya. Dari pendapat lain mereka kurang tertarik melakukan investasi dalam saham dengan alasan mereka takut akan resiko kerugian, oleh karena itu mereka cendrung menabung di Bank karena Bank uang mererka akan aman dan walaupun bunganya sedikit. Mereka membayangkan ketakutan tenang kehidupan mereka setelah pensiun nanti, ketakutan dalam memenuhi kebutuhan kehidupan mereka dengan adanaya perubahan gaya hidup dana kenyamanan hidup serta bagaimana mempersiapkan masa depan anak-anak mereka.

Dari sisi perencanaa keuangan Baby Boomer 10 orang reponden dari 15 orang responden merencanakan keuangan mereka dengan menabung sebagian uang pensiunan yang mereka terima dan setengahnya lagi akan mereka gunakan untuk kegitan usaha dengan mengunakan jasa konsultan untuk membuat perencanaan keuangan mereka sehingga mereka bisa memprediksikan berapa keuntungan yang akan mereka peroleh dari kegiatan usaha tesebut. Untuk pengelolaan keuangan, sebagaian responden bingung dalam penglolaan keuangannya, karena mereka tidak mengetahui pasti kehidupan mereka seperti apa kedepannya, dengan adanya uang pensiunan yang mereka terima nanti bisa menghidupi keluarganya dan tidak mau mengambil resiko dalam melakukan investasi dalam bentuk saham. Dan sebagian lagi mereka lebih mempercayakan pengelolaan keuanga mereka dengan menggunakan jasa konsultan, sehingga jelas pengeluaran uang mereka itu untuk kepeluan apa dan seberapa penting keperluan mereka tersebut sehingga tidak ada uang yang tebuang percuma. Karena disi lain ada keluarga yang akan mereka biayai, kebutuhan untuk anak-anak mereka memaski perguruan tinggi yang biayanya cukup mahal. 


\section{DAFTAR PUSTAKA}

Ahmad Tanzeh dan Suyitno, DasarDasar Penelitian,( Surabaya: Elkaf, 2006)

Arikunto, Suharsimi. 2016. Prosedur Penelitian: Suatu Pendekatan Praktik. Jakarta: Rineka Cipta

Budisantoso,Indrasto, Gunanto,2002, Cara Gampang Mengelola Keuangan Pribadi dan Keluarga,PT.Gramedia Pustaka Utama,Jakarta

Darisman A and Widianto M. H. (2019). Design and Development of Pharmaceutical Company Information System based on Website Using The Waterfall Model. International Journal of Recent Technology and Engineering. Binus Univercity, 8. Retrieved from URLhttps://research.binus.ac.id/pub lication/A38A70EA-

Jurkiewicz, C. L. (2000). Generation X and the Public Employee. Public Personnel Management, 29(1), 55.

Lexy J. Moleong, Dr. M.A. Metodologi Penelitian Kualitatif (Edisi Revisi)Darisman A and Widianto M. H. (2019). Design and Development of Pharmaceutical Company Information System based on Website Using The Waterfall Model. International Journal of Recent Technology and Engineering. Binus Univercity, 8. Retrieved from URL

Liman ,N., \& L. P. H. (2009). Financial Planning Determination of Retirement Fund For Indonesian People. Journal of Applied Finance and Accounting, 247.

Lusardi, A., \& Mitchell, O. S. (2008). How much do people know about economics and finance? Financial Illiteracy and the Importance of Financial Education. Policy Brief, (5).

Lusardi, A., \& Mitchell, O. S. (2011).
Financial literacy and retirement planning in the United States. Journal of Pension Economics and Finance, 10(4), 509-525. http://doi.org/10.1017/S147474721 100045X

Mitchell, O. S. (194AD). How boomers save. American Demographics.

Paidi. (2013). Strategi persiapan masa pensiun bagi para karyawan. EJournal WIDYA Ekonomika, 1(1), 12-17.

Strauss, W., \& Howe, N. (1999). Generations: The history of America's future, 1584 to 2069. New York: William Morrow \& Co.

Sundjaja, R. S., Barlian, I., \& Sundjaja, D. P. (2010). Manajemen keuangan Edisi Ketujuh / Ridwan S. Sundjaja, Inge Barlian, Dharma Putra Sundjaja.

https://megapolitan.kompas.com/read/20 11/03/28/11285253/9.dari.10.orang. belum.siap.pensiun?source $=$ autonex $\mathrm{t}$

Twenge, J. M. (2006). Generation Me: Why Today's Young Americans Are More Confident, Assertive, Entitled-and More Miserable Than Ever Before. New York: Free Press www.bisnis.news.viva.co.id www.infobanknews.com 